\title{
Considerations on the ethic-aesthetic dimension of design
}

The emotions that accompany, define and describe, the beauty and appeal provoked by the objects of design, are herein analyzed from an ethic-phenomenological perspective. The objective is to prove how ethics and aesthetics, in relation to design, lay out enigmas that force the paradoxes to transcend themselves. Ethics and aesthetics of design are both on the same side of a coin; they facilitate the creation, through objects and images, of scenarios needed for cultural interactions, they demand rights and they help the social construction of taste.

keywords design, ethics, aesthetics, consumer society

\section{Introduction}

Usually, design is seen as the engine that moves desire in contemporary societies. Our daily lives are saturated with objects, images, and spaces; which show us aesthetic shapes that are renewed constantly to satisfy us. However they can never fulfill our desires completely, as it would make the consumer society collapse. Desire as well as design, share traits that link subjective ethic forms. On one level, they are both social productions, organized by means of a repression-permission game; they are produced and reproduced collectively (Deleuze \& Guattari 2004). On another level, they are also stimulated by the power offered by otherness. Therefore, it is thanks to this power, that design and desire are critical carriers of participation and experience. Thus, every symbolic form, materialized into a product of design, is also a critical carrier of desire and is subjective to what is real.

Consequently, it is undeniable that design is important in the télos of our lives. Speed, efficacy, comfort, functionalism, sustainability and many other myths, are just a few examples of how design manages to turn into products the collective desires and ideals characteristic of postindustrial societies. The way these myths get converted into complex social narratives full of sense, is through aesthetics. Although, to understand why this happens, it is necessary to leave behind the restrictive character of modern aesthetics, which through categories, ends up limiting itself to the world of art alone. Rather, it is necessary to assume it as the sensible appreciation that is drawn from our daily routine, which allows us to adopt the language of socialization, the reciprocity of opinions, the flourishing of taste and the strengthening of dialog. 


\section{The aesthetics of design as a cohesive field in daily life}

The correlation between aesthetics and design opens up in different ways. In the one hand, the designer has as task of creating aesthetic forms that express the interests of the different actors, in the chain of production, consumption and disposal. On the other hand, he takes advantage of the cohesion that aesthetics naturally generate in daily life, by stimulating the interests of ' ' obtaining pleasure, calming curiosity, comprehending, exciting, expressing, entertaining, impressing and emotionally nourishing oneself ' ' (Mandoki, 2006: 31). That is how the aesthetics of design activates processes of interaction, communication, and language. By taking advantage of these two aspects, is how design produces and reproduces myths, which resolve the disturbing conflicts and contradictions that arise between people's beliefs and their everyday experiences.

In a world where consumerism constitutes the free-expression of the individuals; the aesthetic of design plays a crucial role. Naturally, in sociology, anthropology and particularly in economics, the aesthetic of design becomes the blank of extreme criticism. On each of the mentioned disciplines, it has not been easy to escape the empiric observations, to which design is simply a medium of change, of circulation; an instrument of accumulation, a source of desires, ambitions, dreams and passions. Precisely, this is why it is ends up being reduced to, only, criticizing the values that relate merchandise to social phenomena Although, design has intrinsic economic aspects, its aesthetics make it a carrier of social elements that are fundamental for understanding, the production of collective imaginaries and the configuration of identities.

As design and aesthetics relate symbolism to language, it is necessary to overcome the idea that design is limited, exclusively, to guide the production of goods and services. In spite of, the importance that aesthetics has in creating and comprehending bonds, in social life, it is trivial the amount of studies made about it. On the contrary, when we talk about the aesthetics of design, special emphasis is made in the stylization, evolution and innovation of the shape of the products. Generally, this is the version that is found in literature; centered on recreating the groundbreaking evolution of form and style. In fact, it is quite interesting to see the way in which the aesthetic shapes are associated with an ideology of progress and with inventions that aim to disrupt everyday life. Even though, this perspective is very popular, it turns out to be very limited in its foundation. The reason, is that it proposes that the aesthetic shape is taken as the status quo of design, forgetting that there is no stable form and that the aesthetic aspects that emerge from the material culture, respond to subjective ethic forms. The emphasis on the study of aesthetic shapes has privileged an irrational interest in studying the "poetic" of design. Which explains the importance of the methods of creation and the beauty of the products. This ends up favoring the study of transcendent pieces of design and the authors that through shape have created milestones of implicit beauty (Tusquets, 1994: 93). Nevertheless, what most design critics seem to forget is that the aesthetic of design builds a social reality based in understanding. In other words, we could talk of the mundane of design, which inquires about how men live their everyday life and about the impact material culture has when creating a network of social relations. This viewpoint establishes a significant topic for contemporary philosophy, in which the importance of an interdisciplinary approach is recognized. Due to the abusive use of life ideals, of the abstract logic, of the philosophy of consciousness, and in general of a whole lot, that tend to disassociate the academic from the practical. In real contexts, men walk away from factual life, from the philosophy of language, from the world of action and communication. And this is where design and its aesthetics occupy a central place in contemporary thought. 


\section{Ethics, aesthetics and material culture}

Furthermore, it is evident that material culture is converted into a vital form of the ethics. That is why sensible experiences that originate in design and have desire behind them, allow men to inquire about self-fulfillment. Who am I? What do I want to do with my life? Or, what can I expect? Questions, in which individual and collective subjectivity are built, nowadays. Even though, wanting, desiring and wishing are the main forces that move consumer society, it is in the mundane dimension of the aesthetics of design where a fertile ground is found; formed by collective actions, which enable the possibility of claiming rights, of social integration, of mobility and mainly of respecting and strengthening dignity.

In the same way, that acquiring, accumulating, eliminating and replacing goods; trigger our aspirations, which are part of the dynamics of production; design establishes itself, in collective action, to give meaning and strength to rights and social integration. To put it more simply, design makes the different ways of looking, feeling and thinking, converge. It is a point of view, in which material culture accounts for a shared ethic and aesthetic. The shapes as attributes of things affect the senses and lead to feeling engaged in a community; by portraying its necessities and taking action, they end up seeking the wellbeing of all the community.

This broad point of view, that makes ethics and aesthetics inseparable, gains power during the Industrial Revolution. More than just developing machines and tools, and inventing serial production, this chapter in history brought a new way of understanding how shape was constructed and what were its possibilities in social life. It is essential to mention that in ancient times the method of representing or imitating forced humans to look for the shape in the material while during the Industrial Revolution the construction of models, which were, basically, just a combination of practical formulas, permitted more shapes and opportunities.

Breaking with the old paradigm of extracting a shape from preexistent matter to designing explicative models of phenomena, changed material culture forever and brought a lot of benefits for philosophy and the social sciences. At the same time, the modern notion of aesthetics appeared, which converted into a model, aimed to comprehend how men were to live their daily lives. This model's biggest advantage is that is has and ambiguous place between practical philosophy and disciplines like epistemology and ontology. Therefore, aesthetics does not define only one object of study, but it is able to focus on heterogeneous problems.

Of course, we are not talking about the aesthetic of art, interested in the poetic, nor on the aesthetic of the philosophy of art itself. Instead we are talking about the prosaic aesthetics aimed at the study of communicative and interchange phenomena, inserted in the heart of factual life. From that point onwards, it is possible to understand the importance of sensibility in establishing personal relationships and in the different ways of living and communicating. Consequently, prosaicism gains a primal role inside anthropology and sociology, by showing how sensibility operates at the epicenter of relationships and social interchanges that make up men's daily lives.

The dimension of aesthetics directly related to ethics, which caught Kant 's attention, is the same face of aesthetics that is linked to manners, rituals, myths, the forms of language and so many other things. Hereon, the aesthetics, of material and visual culture, works as a stage for eroticism, according to which, it is possible to share with others the dimension 
theme 1

theory strand 3

aesthetics beyond style

of beauty, comfort, and appeal contained in daily pleasures. It is the same aesthetics, praised in advanced capitalism, with multiple purposes and senses because it explores the emotional factor and the emotional community.

This suggests to open up to the possibility of thinking differently, rather than just thinking of satisfying our individual needs; consuming, is a horizon of sense that generates new ethical judgments, reaffirms- between so much diversity- social groups, and most importantly, projects itself as the setting for social mobility, powered by global interests and concerns.

Consequently, it is not illogical to affirm that the consumerist process of acquisition, possession and experience, defines the culture of today's world, and specifically it produces each individual; making it a mechanism that allows us to participate in the quotidian, in the customs, in the State and in globalization. Consumerism, more than just convening the imminent forms of social exclusion; it is worthy to think of it as the support that helps overcome egocentrism through inclusion of otherness, as the support for processes in design.

Therefore, when speaking of the user centered design (Norman, 1990: 230-264) of friendly design (Blanco, 2007: 78). Or of inclusive design; it becomes an indication for a new phase of economic development; linking ethics, morality and of course, aesthetics. This concepts stimulates an affectionate behavior between the object and the user: "the product not only possess this trait for the mere fact that it works fine, it lasts longer, or it wears less, but fundamentally because, immerse in a semiotic, emotional, ritual or mythical world appeals to some characteristics of our personality, of our genetic or ethnic history, therefore bonding profoundly with the receptor. The objects goes from being a mere tool that solves problems or provides services, to being our companion that actively participates in our time and is inserted in our space in a special way. Maybe this is why we need to see it permanently, to make sure it is still there, like those memories of trips or vacations, like the fetishes that decor youngsters rooms" (Blanco: 78). In all of this, goods and services are seen as the basic elements for establishing social bonds. In brief, the concerns of designers and consumers have been modeled to make evident the correlation between human experience and consumerism. This is the reason for which the assimilation of myths and desires, that make aesthetic and emotional pleasure more evident, is abundant everywhere; and at the same time the pillars of ethics attempt to explain the behaviors derived from the sphere of consumerism.

\section{Conclusion}

In conclusion, this piece is only the starting point for a topic that is yet to be explored. In the rational dimension of design, there also exists an aesthetic dimension. The aesthetic experience fights for the recognition of common wellbeing; fights for pluralism, for difference of opinion, of taste; fights for social inclusion; fights for the environment; fights for dignity.

This implies that, the final purpose, of the aesthetics of design, is to live with dignity, is to live well. By taking advantage of its secularity and massiveness, design must focus in promoting a better, fairer life; in which each of these aspects become vital for human life. Design should be assumed as a way of life, as a political-ethical exercise that seeks collective happiness. It is time to go beyond, enclosing the study design, to opening it up, by extending its historical, social and cultural content. This would mean, that through design, new and varied ways of portraying experiences, need to be created, so that they 
can be useful for enriching life, respect and the creative spirit. In other words, new ways need to be created, so that the practical nature of design can be seen; and the objects made through design can be at the service of the community. Under this logic, ethics and aesthetics, stop being tied down to existentialist dilemmas; and design turns into the practice of living aesthetically.

However, beneath all of this, a challenge exists, a challenge of finding new methods of securing individuality, as a right; and of establishing new social links. Design must reestablish the stoicism that looks for an exemplary life and for the recognition of the importance of sharing in society. Only there can men feel that their natural dispositions are being used properly.

Putting into perspective the aesthetics of design inside human existence and relating it to the way we organize our lives, also implies the revitalization of philosophy. The key points for accomplishing this task, are scattered throughout continental philosophy, but are summarized, by Wittgenstein in the Tractatus, when he affirms that ethics and aesthetics are the same thing (2003: 269). According to our interests, this simple but profound affirmation, makes us think, that design is an abstract structure created for the life that demands the aesthetical recognition; and that directs creative potential.

In brief, the essence and the value of design, are not found in the objects we consider design, but in the dynamics and experimental development, in which they are created and perceived.

\section{References}

Blanco, R. (2007) Notas sobre diseño industrial. Buenos Aires: Nobuko Deleuze, G. \& Guattari, F. (2004) El Anti Edipo: Capitalismo y esquizofrenia, Barcelona: Paidós

Kant, I. (2001) Historia para una historia universal en clave cosmopolita. En: Ideas para una historia universal en clave cosmopolita y otros escritos sobre filosofía de la historia. Madrid: Tecnos Norman, D. (1990). La psicología de los objetos cotidianos, Madrid: Nerea Mandoki, K. (2006). Estética cotidiana y juegos de la cultura. Prosaica 1. México: Siglo XXI Tusquets, O. (1994). Más que discutible. Barcelona: Tusquets Editores Wittgenstein, L. (2003). Tractatus logico-philosophicus. Madrid: Tecnos, 
